\title{
Refeições e comportamentos à mesa: um estudo a partir de consumidoras urbanas ${ }^{1}$
}

\author{
Marcio Gazolla \\ Universidade Tecnológica Federal do Paraná - Pato Branco - PR - Brasil \\ ORCID: https://orcid.org/0000-0002-4807-6683 \\ Pahola Viecelli \\ Universidade Tecnológica Federal do Paraná - Pato Branco - PR - Brasil
}

\begin{abstract}
Resumo
O objetivo desse estudo é discutir as dinâmicas e os comportamentos alimentares acerca do consumo das principais refeições realizadas no ambiente doméstico de consumidoras urbanas. Para isso, a metodologia quanti/qualitativa foi construída a partir de uma pesquisa de campo realizada com 43 consumidoras pré-selecionadas de acordo com seu perfil socioeconômico e local de moradia, no Município de Pato Branco/PR. O instrumento de pesquisa foi um questionário, baseado em questões de múltipla escolha, aplicado individualmente no domicílio de cada participante. Utilizou-se ainda de diário de observação de campo, registrando impressões da pesquisadora a partir de falas e depoimentos das interlocutoras. Os resultados indicam que as refeições realizadas ao redor da mesa representam, simbolicamente, uma prática importante como espaço da família, das conversas, da troca de informações e de diálogos que servem também como forma de sociabilidade do grupo domiciliar. Além disso, lançar luz sobre a estrutura das refeições contemporâneas, possibilitou compreender que as transformações do comer decorrentes da modernidade alimentar - evidenciada por um movimento de maior homogeneização e individualização da alimentação - não se limitam unicamente a reprodução das condições alimentares de contextos hegemônicos e dos interesses agroindustriais.
\end{abstract}

Palavras-chave: Alimentação. Consumo alimentar. Refeições. Hábitos alimentares. Desenvolvimento humano.

\section{Abstract}

Meals and table behaviors: a study from urban consumers

The aim of this study is to understand and analyze the eating habits and behaviors related to the structure of daily meals of urban consumers. The quantitative / qualitative methodology was built from a field research conducted with 43 consumers and preselected consumers according to their socioeconomic profile and place of residence, in Pato Branco/PR. The research instrument was a questionnaire, based on multiple choice

1 Uma primeira versão desse estudo foi apresentada no II Workshop - WEAA - Estratégias Alimentares e de Abastecimento, na data de 14 de setembro de 2019 em Porto Alegre - RS. 
questions, applied individually at each participant's home. A field observation diary was also used, recording the researcher's impressions from speeches and statements by the interlocutors. The results indicate that meals around the table symbolically represent an important practice as a family space, conversations, information exchange and dialogues that also serve as a form of sociability of the home group. In addition, shedding light on the structure of contemporary meals has made it possible to understand that the transformations of eating resulting from food modernity - evidenced by a movement of greater homogenization and individualization of food - are not limited solely to the reproduction of eating conditions in hegemonic contexts and agro-industrial interests.

Keywords: Food. Food consumption. Meals. Eating habits. Human development.

\section{Comidas y comportamientos em la mesa: un estúdio com consumidores urbanos Resumen}

El objetivo de este estudio es comprender y analizar los hábitos y comportamientos alimentarios relacionados con la estructura de las comidas diarias de los consumidores urbanos. La metodología cuantitativa / cualitativa se construyó a partir de una investigación de campo realizada con 43 consumidores y consumidores preseleccionados de acuerdo con su perfil socioeconómico y lugar de residência, em Pato Branco/PR. El instrumento de investigación fue un cuestionario, basado en preguntas de opción múltiple, aplicado individualmente en la casa de cada participante. También se utilizó un diario de observación de campo, registrando las impresiones del investigador de los discursos y declaraciones de los interlocutores. Los resultados indican que las comidas alrededor de la mesa representan simbólicamente una práctica importante como espacio familiar, conversaciones, intercambio de información y diálogos que también sirven como una forma de sociabilidad del grupo de origen. Además, arrojar luz sobre la estructura de las comidas contemporáneas ha permitido comprender que las transformaciones de la alimentación resultantes de la modernidad de los alimentos, evidenciadas por un movimiento de mayor homogeneización e individualización de los alimentos, no se limitan únicamente a la reproducción de las condiciones alimentarias en contextos hegemónicos e interesses agroindustriales.

Palabras clave: Alimentación. Consumo de alimentos. Las comidas. Hábitos alimentícios. Desarrollo humano.

\section{Introdução}

É sabido que os modos de vida ao longo da história se modificam, consequentemente, as maneiras de comer e de se estar à mesa também. Nos termos de Giddens (1991), a modernidade proporciona uma série de mudanças, inclusive, nas relações de comensalidade e na identidade alimentar daqueles que se alimentam, podendo assim, interferir nos hábitos, nos horários, locais das refeições, no consumo e na produção de alimentos. Nesse cenário, as modificações têm sido intensificadas nos últimos 40 anos, especialmente, em função da crescente modernização da agricultura e da produção de alimentos, bem como por uma maior reflexividade por uma parte dos consumidores tendo em vista o consumo de alimentos proveniente deste tipo de agricultura e indústria alimentícia (BAUMAN, 2008).

Na contemporaneidade, a sensação de viver um tempo acelerado e o ritmo avançado para realização das demandas sociais, têm sido apontados como um fator 
preponderante na diminuição dos encontros cotidianos entre familiares e amigos, do compartilhamento da comida, da manutenção de horários fixos para as ingestas, da produção do próprio alimento e também das dinâmicas das refeições ao redor da mesa. É nesse sentido que se discute a respeito de uma redução dos encontros em âmbito doméstico para a realização das principais refeições do dia e da sociabilidade proporcionada através delas.

Essas tem sido substituídas por outros locais fora do espaço privado como no caso de restaurantes, lanchonetes e redes de fast food ou por uma maior autonomia dos comensais que passam a preparar seus próprios alimentos de forma individualizada. Além disso, dados da última Pesquisa de Orçamentos Familiares (POF) 2017-2018, apontam que parte do conteúdo das ingestas tem sido motivado por aspectos de praticidade a partir do consumo de produtos prontos, semiprontos ou lanches industrializados, caracterizados principalmente por sua facilidade e rapidez no preparo.

Tendo em vista tal panorama, o propósito deste trabalho não é desconsiderar outros modos e hábitos de consumo da comida e, por conseguinte, outras formas de vida, haja vista a complexidade teórica, empírica e de todos os fatores sociais envolvidos nas escolhas humanas. Contudo, evidenciar se as condições nas quais os atores sociais investigados, se assemelham as perspectivas contemporâneas do consumo de alimentos, a fim de entender se esses tem incorporado práticas e tendências de contextos mais amplos como os dos grandes centros urbanos.

Dessa forma, o consumo de alimentos e a maneira como ele acontece é um importante processo social com potencial para captar mudanças nos aspectos sociais, culturais e de desenvolvimento das sociedades contemporâneas. Entender as escolhas, os hábitos de consumo, o sistema de refeições, as tendências alimentares e outros temas relacionados a comida torna-se essencial na atualidade, além de conectá-los com os processos de desenvolvimento humano. Diante disso, trazer à luz alguns elementos de compreensão a respeito das refeições, suas dinâmicas e comportamentos à mesa, contribui para a compreensão de fatores preponderantes do consumo alimentar e das atividades que se inter-relacionam ao ato de comer.

O objetivo desse estudo, portanto, é discutir as dinâmicas e os comportamentos alimentares acerca do consumo das principais refeições realizadas no ambiente doméstico de consumidoras urbanas do Município de Pato Branco/PR. Para isso, realizou-se uma pesquisa empírica com 43 consumidoras de alimentos pré-selecionadas de acordo com seu perfil socioeconômico (levando-se em conta a renda domiciliar, construiu-se quatro perfis - A, B, C e D) e local de moradia. $O$ instrumento de pesquisa foi um questionário, baseado em questões quantitativas de múltipla escolha, aplicado individualmente no domicílio de cada participante. Além disso, utilizou-se de diário de observação de campo, registrando impressões da pesquisadora a partir das falas e depoimentos das interlocutoras.

Além dessa introdução inicial e das considerações finais, o trabalho está estruturado da seguinte maneira: uma seção contendo o percurso metodológico da pesquisa; uma de revisão teórica sobre os sistemas de refeições no Brasil e a última de resultados e análises em torno da dinâmica das refeições, da comida e sua presença no cotidiano das consumidoras investigadas. 


\section{Procedimentos metodológicos da pesquisa}

$\mathrm{O}$ artigo tem como base um estudo empírico da população urbana de Pato Branco/PR, localizado na Região Sul do Brasil. Segundo estimativas do Censo Demográfico (IBGE, 2010), possui um grau de urbanização em torno de 94,09\%, o qual diferencia-se dos demais municípios da Mesorregião Sudoeste da qual faz parte, considerada a segunda região menos urbanizada do Paraná com cerca de $30,42 \%$ da sua população em zona rural. Nos últimos anos Pato Branco tem se destacado em termos de qualidade de vida não apenas no sentido econômico, mas de vários outros indicadores relacionados a fatores sociais como saúde, educação, renda e tecnologia. Em vista disso, a importância de compreender alguns aspectos vinculados a alimentação e aos hábitos alimentares de seus consumidores, considerando um município de tamanho médio que vem se diferenciando em termos de desenvolvimento local, regional e humano.

Para a realização da pesquisa, optou-se pelo seguinte caminho metodológico: realizou-se o cálculo da amostra com base na população finita, tendo como dado secundário o último Censo Demográfico do IBGE (2010). A partir de dois critérios principais: número de domicílios por bairro e rendimento mensal domiciliar per capita, resultou-se em um total de 43 consumidoras distribuídas em diferentes bairros urbanos. Considerou-se um total de 44 bairros e 22.734 domicílios, levando em conta um erro amostral de $15 \%$. Justifica-se o erro amostral elevado devido a necessidade de diminuição da amostra e, consequentemente, do universo pesquisado, a fim de condizer com o tempo e os recursos disponíveis para a pesquisa.

A fase seguinte foi o agrupamento dos bairros em que os classificou nas seguintes categorias: a) Bairros de categoria socioeconômica ' $A$ ': domicílios com rendimentos mensais acima de 5 salários mínimos; b) Bairros de categoria socioeconômica ' $B$ ': rendimentos domiciliares na faixa de 2 à 5 salários mínimos; $C$ ) Bairros de categoria socioeconômica ' $C$ ': rendimentos domiciliares na faixa de 1 à 2 salários mínimos; d) Bairros de categoria socioeconômica ' $D$ ': rendimentos na faixa de $1 / 8$ à 1 salário mínimo.

Após, realizou-se a seleção do número de bairros a serem pesquisados, a partir da média dos domicílios de acordo com o agrupamento por classes de rendimentos. A classificação foi feita do maior para o menor número de domicílios existente em cada bairro. Inicialmente houve o sorteio das ruas a serem pesquisadas, para seguir critérios de aleatoriedade, contudo, no decorrer do estudo optou-se pelo método de indicação, em que cada participante indicava ou informava outro possível participante, possibilitando um número menor de rejeições durante a coleta de dados. Todavia, manteve-se o critério em relação aos bairros selecionados inicialmente e ao propósito de entrevistar pessoas que correspondessem o perfil socioeconômico do referido bairro.

O instrumento utilizado para a coleta de dados foi um questionário adaptado de Barbosa (2007) denominado de 'Pesquisa de Hábitos Alimentares dos Brasileiros'2. Para esse estudo selecionou-se as seguintes questões do roteiro de 
perguntas: número de refeições realizadas no domicílio, divisão das refeições, quais são as realizadas coletivamente, representações sobre as refeições tomadas diariamente (café da manhã, almoço e jantar) e atividades realizadas durante a ingesta.

A aplicação dos questionários foi feita individualmente no domicílio de cada respondente responsável pela compra, seleção e preparo dos alimentos ${ }^{3}$. A coleta de dados teve início em agosto do ano de 2018 considerando diferentes dias da semana e finais de semana em três turnos de horários diferentes (manhã, tarde e noite). O propósito foi acessar indivíduos que, por exemplo, realizam todas as suas refeições fora de casa ou trabalham durante a semana e estejam presentes nos domicílios somente nos fins de semana ou no período noturno.

Estabeleceu-se previamente quatro perfis de consumo ( $A, B, C$ e $D)$, conforme a classificação dos bairros acima mencionadas. No Quadro 1, visualiza-se a distribuição da amostra segundo a classificação por perfil de rendimento, o número de consumidoras pesquisadas, os respectivos bairros e a identificação das consumidoras investigadas.

Quadro 1 - Distribuição da amostra por classe de rendimento e bairros

\begin{tabular}{|c|c|c|c|}
\hline $\begin{array}{l}\text { Perfil de } \\
\text { consume }\end{array}$ & $\begin{array}{c}\mathrm{N}^{\circ} \mathrm{de} \\
\text { consumidoras }\end{array}$ & Bairros pesquisados & $\begin{array}{c}\text { Identificação das } \\
\text { consumidoras }\end{array}$ \\
\hline Perfil 'A' & 3 & Centro; Brasília; La Salle & $1 ; 7 ; 10$ \\
\hline Perfil 'B' & 9 & $\begin{array}{l}\text { Santa Terezinha; Menino Deus; La } \\
\text { Salle; Brasília; Vila Isabel; Fraron; } \\
\text { Centro; Jardim } \\
\text { Pinheirinho }\end{array}$ & $\begin{array}{c}2 ; 4 ; 5 ; 6 ; 8 ; 9 ; 12 ; 19 ; \\
27\end{array}$ \\
\hline Perfil 'C' & 15 & $\begin{array}{l}\text { São Cristóvão; } \\
\text { Horizonte; Cristo Rerada; Pinheirinho; } \\
\text { Industrial; São Vicente; Santa } \\
\text { Terezinha; Menino Deus; La Salle; } \\
\text { Fraron; Planalto I; Centro; Planalto II; } \\
\text { Santo Antônio }\end{array}$ & $\begin{array}{c}3 ; 11 ; 13 ; 14 ; 17 ; 18 ; 21 ; \\
22 ; 25 ; 28 ; 29 ; 30 ; 31 ; \\
34 ; 36\end{array}$ \\
\hline Perfil 'D' & 16 & $\begin{array}{l}\text { São Cristóvão; Alvorada; Novo } \\
\text { Horizonte; Santo Antônio; Morumbi; } \\
\text { Cristo Rei; Pinheirinho; Industrial; } \\
\text { Santa Terezinha; La Salle; Planalto I; } \\
\text { Centro; Jardim Floresta; Sudeste; } \\
\text { Bela Vista; Planalto II }\end{array}$ & $\begin{array}{c}15 ; 16 ; 20 ; 23 ; 24 ; 26 ; \\
32 ; 33 ; 35 ; 37 ; 38 ; 39 ; \\
40 ; 41 ; 42 ; 43\end{array}$ \\
\hline Total & 43 & - & - \\
\hline
\end{tabular}

Fonte: Elaboração própria (2018), a partir dos dados do IBGE (2010).

Para análise dos dados utilizou-se de métodos quantitativos e qualitativos, a fim de aprofundar os entendimentos, interpretações e os significados no desenvolver do estudo. A análise quantitativa foi realizada no Microsoft Excel (construiu-se um banco de dados), caracteriza-se pelo emprego de estatística

habitantes cada. Agradece-se à Lívia Barbosa pela colaboração e apoio ao ceder o questionário, que foi reestruturado e modificado, servindo de inspiração para essa pesquisa.

${ }^{3}$ Este estudo não se trata de um recorte de gênero, contudo, considerou-se a escrita no feminino tendo em vista que a amostra foi significativamente composta por interlocutoras mulheres. 
descritiva, tendo em vista, medir indicadores em termos de perfis de consumo com base nas quatro classes sociais de rendimento domiciliar. O sentido qualitativo da pesquisa ocorreu a partir de observações de campo in loco na qual, junto ao questionário, foram realizadas anotações sobre aspectos contidos nos depoimentos e falas de cada participante, considerando suas principais percepções, reflexões e comportamentos subjetivos aos alimentos e a suas refeições.

\section{Sistemas de refeições no Brasil}

As refeições e suas composições são construções culturais históricas, cujo consumo de alimentos elucida a interdependência entre fatores biológicos, sociais e culturais. Dessa forma, comer constitui-se em atitudes ligadas aos usos, costumes e situações a partir de formas específicas de manipulação, preparo e consumo da comida. As refeições tratam-se, portanto, de momentos da vida cotidiana, que implica um processo específico de preparar, servir e ingerir os alimentos, quase sempre realizadas por meio de uma sociabilidade procedente dos indivíduos que se encontram ao redor da mesa (CANESQUI; GARCIA, 2005).

Segundo Cascudo (2011), as refeições fazem parte de um complexo sistema de normas e regras alimentares, organizadas e classificadas de maneira particular por cada sociedade, grupo social ou indivíduo. Nessa perspectiva, elas obedecem a uma dada ordem em que determinadas comidas são ingeridas em detrimento de outras, considerando uma sequência ordenada ou não dentro de uma lógica de ingestão e de combinação dos alimentos. Barbosa (2007) corrobora ao dizer que, os sistemas de refeições, possibilitam compreender dinâmicas culturais e sociais que orientam os comportamentos à mesa, informam a respeito de práticas alimentares, valores utilizados na escolha dos cardápios, na ingestão da comida e nos contextos sobre as tendências alimentares.

A esse respeito, Fischler (1995) observa que existem princípios de grande complexidade que governam o consumo dos alimentos, por sua vez, repercutindo também no comportamento dos comensais. Conforme o autor, o comportamento relativo à comida relaciona-se diretamente ao sentido dos seres humanos com sua própria identidade social e, por isso, ao comer coloca-se no prato muito mais do que as preferências gastronômicas, culinárias ou critérios nutricionais e de saudabilidade. No prato, além do alimento, cabe ainda dimensões que mobilizam aspectos simbólicos, sociais, ambientais, históricos e políticos que fazem parte de um modo de vida, uma certa identidade que, por sua vez, é (re) produtora de sentidos e signos sociais que pautam escolhas influenciadas por um dado contexto sociocultural (MINTZ, 2001).

Historicamente as refeições são consideradas momentos ritualísticos da família e da união entre amigos, cujo costume era mantido na coesão de horários e atividades coletivas. Contudo, na sociedade contemporânea, ocorre, em certa medida, uma transformação no tempo e no espaço das refeições, que passam a estar submetidas cada vez mais a uma organização das atividades pertencentes ao universo privado de cada membro do grupo familiar (CASCUDO, 2011).

Poulain (2013) escreve a respeito de uma desestruturação das refeições como consequência de uma série de transformações que acompanham a modernidade alimentar e as práticas de consumo. Giddens (1991), a respeito dessa 
modernidade, afirma que os modos de vida tendem a propiciar modificações nas relações de comensalidade e na própria identidade alimentar dos indivíduos, podendo ainda interferir nos hábitos alimentares, nos horários e locais das refeições, no consumo e na produção de alimentos. Segundo o autor, isso acontece, pois, na modernidade há uma ascensão do individualismo, o qual remete os consumidores a decisões outrora tomada pelo coletivo.

Barbosa (2007) compreende que no Brasil, embora existam diferenças entre os subsistemas e as refeições entre si, também existem certas características específicas do comer brasileiro que podem ser observadas na combinatória dos alimentos, nas lógicas de ingestão da comida, nas técnicas de cocção e nas maneiras à mesa. Em geral, as pessoas se alimentam a partir de uma mistura de variados estilos culinários, misturando diferentes alimentos no mesmo prato em uma única refeição. É possível dizer que essas misturas se associam ao pouco conhecimento da origem dos diferentes pratos e da forma como são ingeridos nos seus países e lugares de origem.

A lógica de ingestão dos alimentos é outro aspecto distinto do sistema brasileiro de refeições. As pessoas costumam colocar, ao mesmo tempo, diferentes tipos de comida no prato, mas mantendo-as separadas em pequenas porções e deixando que a combinação entre elas aconteça no interior da boca. A mistura dos diferentes alimentos ainda no prato, por causalidade, está associada à quebra de etiqueta e é vista com repugnância. Nesse caso, ela acontece enquanto elemento constitutivo do prato, associada à cozinha regional ou típica, como é o caso do feijão tropeiro, do baião-de-dois ou do mexido (arroz, feijão, ovo, farinha e restos de feijoada). Outra característica é a presença, durante a semana, de pelo menos duas refeições quentes ao dia, almoço e jantar, compostas de comidas de 'panela', 'de sal' ou de 'gordura'. Pode-se ter em uma mesma refeição, arroz, feijão, farofa, bife, batata frita e salada; diferentes pratos que empregam técnicas distintas de cocção. Além disso, há uma grande informalidade à mesa dos brasileiros e pouca preocupação com a apresentação da comida no prato.

De acordo com Barbosa (2009; 2007) o sistema de refeições no Brasil é subdividido entre: semanal, fim de semana e ritual. O semanal vigora de segunda a sexta-feira na hora do almoço; o de fim de semana inicia-se a partir de sexta-feira e vai até domingo à noite e o ritual vigora em datas específicas coletivas ou individuais. Esses subsistemas diferenciam-se entre si por seus conteúdos, valores e lógicas atribuídos à escolha dos cardápios, seus significados, ao grau de elaboração da comida e de formalidade à mesa, ao local da ingestão, aos atores sociais envolvidos e ao tipo de sociabilidade que predomina em cada um. Esse sistema normalmente é composto de seis refeições ao dia: café da manhã, lanche da manhã, almoço, lanche da tarde, jantar e lanche da noite (antiga ceia). Tal sistema é considerado pelas recomendações médicas e nutricionais modernas do ocidente que afirmam a conveniência de se comer em pequenas quantidades, várias vezes ao dia, tanto para uma boa saúde como para a longevidade. Contudo, vale ressaltar que essa é uma perspectiva generalizada sobre o comer no Brasil, existem modos distintos de se alimentar que consideram outros olhares. 


\section{Dinâmica das refeições: a comida e sua presença no cotidiano}

Essa seção apresenta os resultados obtidos com a pesquisa de campo a partir da aplicação dos questionários às participantes. Primeiramente discute-se os dados em termos gerais da amostra, após os resultados são cruzados em relação aos perfis socioeconômicos de consumo conforme exposto na seção metodológica.

Os resultados indicam que regularmente o número total de refeições realizadas no domicílio das interlocutoras é principalmente de três e no máximo quatro ao dia. Diariamente $32,56 \%$ da amostra afirmou realizar ao menos quatro refeições, dividindo-as entre café da manhã (81,40\%), almoço (86,05\%), jantar (100\%) e lanche da tarde (34,88\%). Igualmente 32,56\% realizam três refeições entre café da manhã, almoço e jantar, ficando fora o lanche da tarde. As divisões dessas ingestas são observadas no Gráfico 1, a seguir.

\section{Gráfico 1 - Divisão das refeições realizadas nos domicílios}

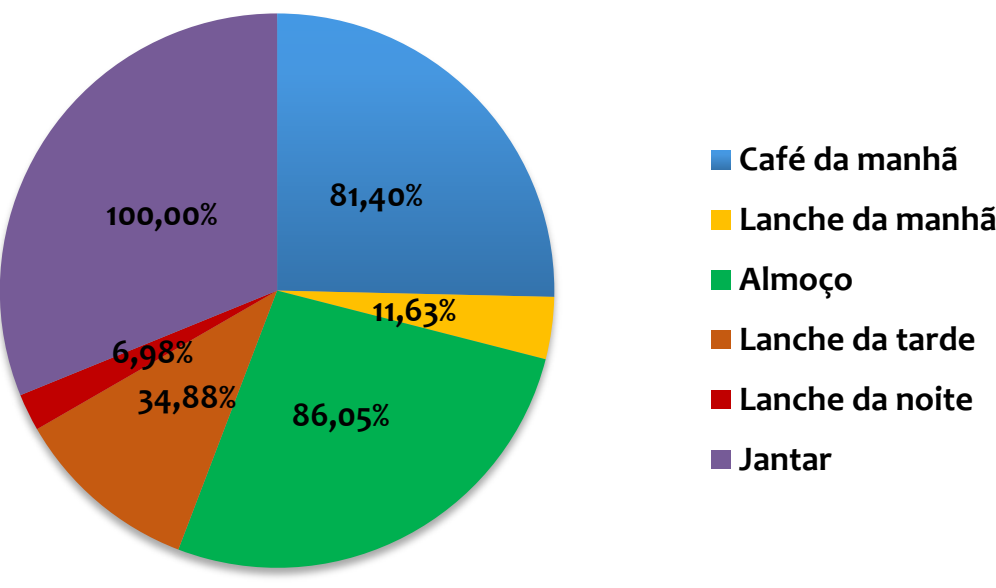

Fonte: Pesquisa de campo (2018).

Outras $18,60 \%$ disseram fazer ao menos duas refeições entre almoço e jantar, enquanto $6,98 \%$ fazem ao menos uma, sendo preferencialmente o jantar. Houve, ainda, 6,98\% que realizam até cinco refeições no domicílio entre café da manhã, lanche da manhã (11,63\%), almoço, lanche da tarde e jantar. Apenas 2,33\% declarou fazer mais de cinco refeições: café da manhã, lanche da manhã, almoço, lanche da tarde, jantar e lanche da noite (6,98\%). Neste caso, especialmente quando há a presença de crianças. De modo geral, em todas as situações declarou-se realizar ao menos uma refeição ao dia no domicílio.

Na pesquisa de Barbosa (2007), o número médio de refeições realizadas pelos brasileiros é de três (44\%) a quatro refeições (40\%). As mais ingeridas são café da manhã (97\%), almoço (96\%) e jantar (91\%), seguidas do lanche da tarde (49\%). Algumas das razões indicadas pelos participantes para a diminuição do número de ingestas foram o ritmo de vida moderno dos grandes centros, a distância entre a casa e o trabalho, o tempo disponível para o almoço e a busca por um padrão estético. É importante enfatizar, nesse caso, que o fato das pessoas declararem ingerir um número menor de refeições durante o dia não significa que elas não comam de fato. A prática do 'beliscar', 'comer porcarias' e até mesmo os lanches ingeridos durante o dia não caracterizam, do ponto de vista cultural, o status de 
uma refeição no Brasil. Essas pequenas ingestas ocupam posições hierárquicas inferiores às refeições principais que, nesse estudo, podem ser entendidas como café da manhã, almoço e jantar.

Em termos de perfil de consumo socioeconômico, esses números variam de um a outro. O Gráfico 2, a seguir, apresenta os resultados do número de refeições realizadas ao dia no domicílio, enquanto a Tabela 1 a divisão dessas refeições. As consumidoras participantes do perfil ' $A$ ' realizam principalmente de três $(66,67 \%)$ a quatro $(33,33 \%)$ refeições, sendo essas divididas entre café da manhã, almoço e jantar, todas com o mesmo percentual (100\%) e, em menor grau, o lanche da tarde (33,33\%). O perfil 'B' faz preferencialmente quatro refeições (33,34\%), seguida de três e cinco (22,22\%). Nesse caso, as refeições dividem-se em café da manhã (100\%), almoço (88,89\%) e jantar (100\%). É possível que esses dois grupos de consumo possam se caracterizar a partir de práticas alimentares atreladas a questões de ordem médicas e nutricionais, por estarem preocupados com a saúde e a boa forma física, atendendo às indicações estabelecidas. Ou ainda, pelo fato de terem disponíveis uma maior quantidade e variedade de alimentos já que são as consumidoras com uma maior renda socioeconômica.

Gráfico 2 - Número de refeições realizadas no domicílio por perfil de consumo

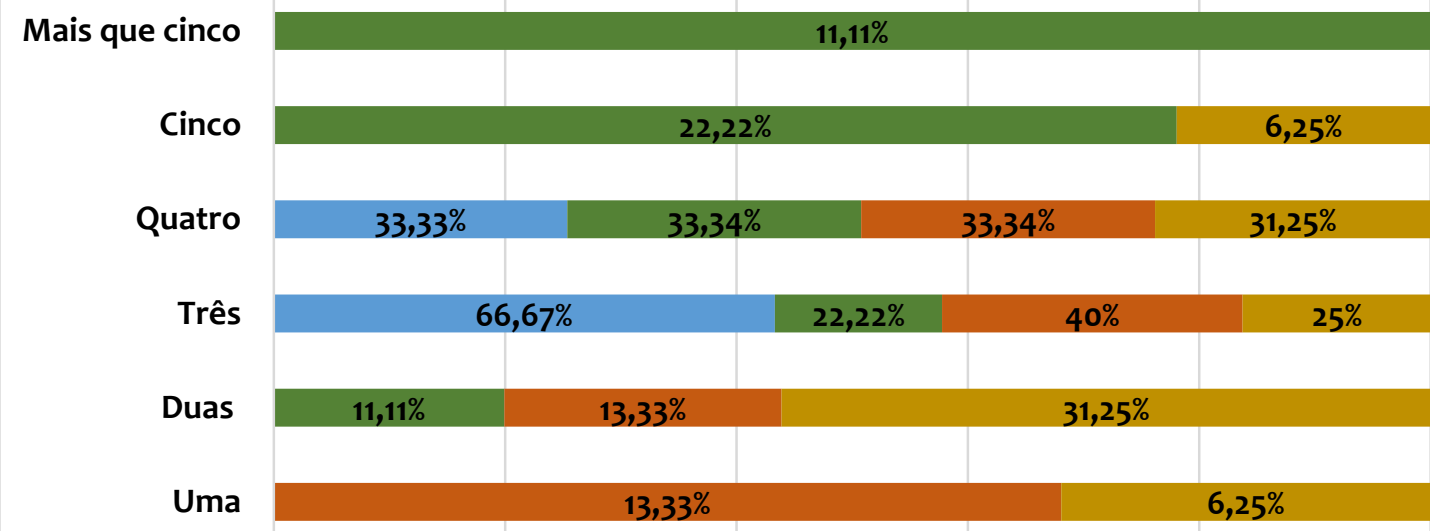

$\square \mathrm{A} \square \mathrm{B} \square \mathrm{C} \square \mathrm{D}$

Fonte: Pesquisa de campo (2018).

Do perfil ' $C$ ', 40\% indicam realizar três refeições; 33,34\%, quatro; $13,33 \%$, duas e uma refeição ao dia no domicílio. O perfil ' $D$ ' faz principalmente duas e quatro (31,25\%), três (25\%) e uma (25\%). Esses perfis são os que concentram os indicadores em termos de menor número de refeições, de 'uma' a 'duas' ao dia. Entre as explicações para isso estão as de que algumas pessoas afirmaram realizar refeições em seus locais de trabalho, casa de amigos ou familiares ou ainda pelo fato de precisarem escolher entre uma refeição e outra por falta de alimentos. Nesse caso, o comer pode estar associado à sobrevivência, a fim de satisfazer as necessidades vitais do corpo, atendendo à sensação de saciedade, como expresso pela Consumidora 42: 'comer bem é comer no almoço e no jantar pra não precisar comer mais durante o dia'. Assim, entende-se o comer relacionado a saúde, às 
preocupações em manter o corpo ativo e a força de trabalho para não passar por privações alimentares (CHEUNG, BATALHA, LAMBERT, 2013).

Tabela 1 - Divisão das refeições segundo o perfil de consumo (\%)

\begin{tabular}{ccccc}
\hline Refeições & Perfil 'A' & Perfil 'B' & Perfil 'C' & Perfil 'D' \\
\hline Café da manhã & 100,00 & 100,00 & 86,68 & 62,50 \\
Lanche da manhã & - & 44,44 & - & 6,25 \\
Almoço & 100,00 & 88,89 & 73,33 & 93,75 \\
Lanche da tarde & 33,33 & 44,44 & 33,33 & 31,25 \\
Lanche da noite & - & 22,22 & - & 6,25 \\
Jantar & 100,00 & 100,00 & 100,00 & 100,00 \\
Nenhuma & - & - & - & - \\
\hline
\end{tabular}

Fonte: Pesquisa de campo (2018).

De modo geral, o café da manhã, o almoço e o jantar são as principais refeições para os quatro perfis de consumo, sendo o lanche da tarde uma opção, mesmo que em menor proporção. Na pesquisa de Panigassi et al (2008), com famílias em situação de insegurança alimentar, os entrevistados relataram fazer as três refeições principais todos os dias, porém o café da manhã em menor proporção (90,60\%) em relação ao almoço (96,10\%) e ao jantar (92,90\%). Esse aspecto também se verifica no contexto desse estudo, ao se constatar que o café da manhã é uma opção reduzida para os segmentos de menor renda, conforme a fala da Consumidora 24, aposentada recebendo um salário mínimo e da Consumidora 40, igualmente aposentada e dividindo a casa com a filha e a neta:

Eu durmo até meio dia pra não precisar tomar café. A gente na verdade, sobrevive da ajuda dos vizinhos e da igreja que dá uma cesta básica por mês. Come o que ganha dos outros, se não, passa fome [...]. (CONSUMIDORA 24: PATO BRANCO/PR, 2018).

A gente quase nunca toma café da manhã aqui em casa por que não tem alimento. Fazer o que, quando tem a gente come. Só a neném que mama. Minha filha recebe o Bolsa Família e eu pego a cesta (proveniente do Centro de Artes e Esporte - CEU) que ajuda. Na cesta vem farinha daí eu faço o pão, mas quando acaba não tem mais. (CONSUMIDORA 40: PATO BRANCO/PR, 2018).

Considerando as narrativas, apesar do café da manhã ser apontado, por pesquisas, como a refeição mais importante do dia, ele é considerado a principal opção de corte na dieta quando em casos de restrição alimentar ou dificuldade de acesso aos alimentos (BARBOSA, 2007). Tal circunstância pode ser explicada pelo fato dele ser considerado mais leve, em comparação ao almoço e o jantar, refeições mais substanciosas. Além disso, constatou-se, assim como no estudo de Barbosa (2009; 2007), que ele é ingerido de forma bastante desordenada e pode ser tomado em diferentes estágios. Come-se um pedaço de pão, de bolo, um gole de café ou uma fruta ao longo da manhã e, dessa forma, muitas vezes, pode ser caracterizado enquanto lanche e não como refeição.

Nesse sentido, a não-realização do café da manhã, enquanto um fator ocasionado pela restrição de alimentos e não como uma escolha, envolve a privação de um dos princípios humanos essenciais para a vida que é o direito de todo cidadão 
a ter acesso a alimentação de qualidade. Compreende-se que o cotidiano vivido por essas consumidoras coloca em questionamento sua dignidade em termos de segurança alimentar e nutricional ao se considerar o pressuposto de que todos devem ter acesso diário, e de forma digna, a alimentos em quantidade e qualidade suficientes para atender suas necessidades nutricionais básicas. De acordo com Sen (1981) a visão de que a fome é causada apenas pela indisponibilidade de alimentos diz pouco sobre o mecanismo causal sobre ela, uma vez que o olhar centrado nos alimentos é uma variável econômica muito remota. Segundo o autor, a capacidade de comandar a própria comida depende muito mais das relações de direito que governam a posse e o uso nas sociedades, as quais se estabelecem nas relações de direito e partem de fenômenos econômicos, questões sociais, políticas e legais.

No país, não é novidade que o debate da carência alimentar resulta de longa data, tendo se acentuado em 2001 com o Projeto Fome Zero, uma proposta de política de segurança alimentar que teve como objetivo principal a eliminação da carestia alimentar. Desde esse período foram criadas políticas públicas a fim de romper com o ciclo da fome de modo a incorporar ao mercado de consumo de alimentos a população de baixa renda, em situação de vulnerabilidade ou excluídas do mercado de trabalho. Diante disso, verifica-se a importância dos alimentos provenientes de políticas governamentais, programas sociais, instituições públicas e auxílios diversos na composição das dietas como se constata a partir das falas acima mencionadas.

Buscando entender as refeições e sua repercussão nas sociabilidades, procurou-se saber em quais delas as comensais compartilham a mesa. O Gráfico 3, a seguir, apresenta os resultados coletados. O jantar é apontado como a refeição que está mais relacionada à sociabilidade por $67,44 \%$ das consumidoras. O almoço é realizado em conjunto em $55,81 \%$ dos domicílios investigados. O café da manhã, em $30,23 \%$ dos casos, acontece de forma compartilhada, sendo a refeição menos relacionada à sociabilidade. Além disso, em $23,26 \%$ dos lares não se realiza nenhuma refeição coletiva e em apenas $6,98 \%$ se faz o lanche da tarde coletivamente.

\section{Gráfico 3 - Refeições realizadas coletivamente}

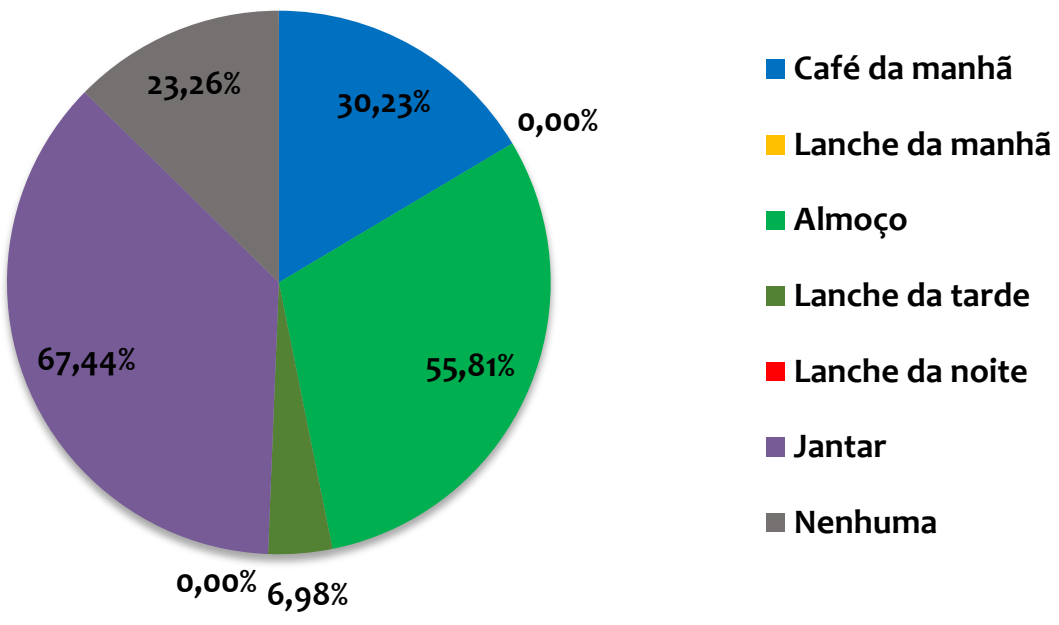

Fonte: Pesquisa de campo (2018). 
Ao verificar as informações por perfil de consumo como exposto na Tabela 2, os dados não apresentam grandes variações em comparação aos resultados gerais da amostra. Grosso modo, o café da manhã, o almoço e o jantar são as refeições mais compartilhadas independentemente da posição socioeconômica do domicílio. Em relação ao café da manhã, o perfil ' $C$ ' é o que apresenta a diferença mais significativa dentre os demais, indicando que apenas $13,33 \%$ das consumidoras 0 realizam de forma coletiva com os demais membros do domicílio. O almoço acontece coletivamente mais para os membros dos perfis ' $A$ ' e 'B' $(66,67 \%)$ em relação aos perfis 'C' (53,33\%) e 'D' (50\%).

Tabela 2 - Refeições realizadas coletivamente segundo o perfil de consumo (\%)

\begin{tabular}{c|c|c|c|c}
\hline Refeições & Perfil 'A' & Perfil 'B' & Perfil 'C' & Perfil 'D' \\
\hline Café da manhã & 66,67 & 44,44 & 13,33 & 31,25 \\
Lanche da manhã & - & - & - & - \\
Almoço & 66,67 & 66,67 & 53,33 & 50,00 \\
Lanche da tarde & - & - & 6,67 & 12,50 \\
Lanche da noite & - & - & - & - \\
Jantar & 100,00 & 88,89 & $53,33 \%$ & 62,50 \\
Nenhuma & - & 11,11 & 20,00 & 37,50 \\
\hline
\end{tabular}

Fonte: Pesquisa de campo (2018).

O jantar, para os quatro perfis, é a refeição mais significativa em relação à reunião familiar. O fato de nenhuma refeição acontecer de forma coletiva no domicílio ocorre para 37,50\% das participantes do perfil ' $D$ ', $20 \%$ para as do perfil ' $C$ ' e $11,11 \%$ para as do perfil ' $\mathrm{B}$ '. Nesse caso, as participantes afirmam morar sozinhas ou realizar parte das refeições em seus locais de trabalho, não coincidindo com os horários dos demais moradores do domicílio. Outras declaram possuir filhos matriculados em creches ou escolas em tempo integral, realizando todas as refeições nesses espaços.

Cabe destacar as perspectivas de Barbosa (2009, 2007) ao dizer que, embora a globalização tenha sido apontada pelo seu papel desagregador, ao estimular a redução do número de refeições em família e a individualização da dieta, na sociedade brasileira as relações ao redor da mesa ainda são consideradas uma prática importante. Nesse caso, a teoria da individualização do gosto não é considerada, ao passo que os dados de sua pesquisa sinalizam para a presença de hábitos alimentares compartilhados e socialmente ancorados nos valores sociais da população. Esse estudo colabora para que se compreenda que, em boa parte das refeições, isso ainda acontece e parece exercer uma representação relevante em termos de sociabilidades, como é ilustrado na fala da Consumidora 13: 'eu gosto da mesa cheia. Quando a gente chama pra comer aparece gente de todo lado'. Assim, a comida e o alimento permanecem enquanto um espaço de encontro, de conversa, socialização, de diálogos entre a família, amigos e os demais membros do grupo domiciliar.

Na tentativa de compreender um pouco mais sobre os sentidos, significados e representações empregados ao consumo da alimentação, buscou-se saber o que pensam as interlocutoras a respeito das refeições. Para isso, foram empregadas questões segundo o grau de concordância, considerando as três principais refeições do dia (café da manhã, almoço e jantar). As alternativas de respostas foram: 
'concordo', 'não concordo nem discordo' e 'discordo'. Nos Quadros 2, 3 e 4 apresentam-se as informações coletadas.

No contexto desse estudo, o café da manhã não é caracterizado como uma refeição familiar, embora seja aquela que preferencialmente se busca fazer em casa (Quadro 2). Nesse sentido, 88,37\% da amostra disse discordar que essa refeição 'une a família', enquanto $83,72 \%$ prefere tomar café no domicílio. Essa pode ser considerada uma refeição bastante individualizada e, por vezes, desordenada devida às atividades dos membros da família ou do grupo doméstico. Habitualmente, durante sua ingestão pouco se fala e quando isso acontece os assuntos giram em torno das obrigações e das tarefas do dia (BARBOSA, 2009).

Quadro 2- Percepções sobre o café da manhã (\%)

\begin{tabular}{|l|c|c|c|}
\hline \multicolumn{1}{|c|}{ Café da manhã } & Concordo & $\begin{array}{c}\text { Não concordo/ } \\
\text { discordo }\end{array}$ & Discordo \\
\hline Mais importante do dia & 48,84 & 0,00 & 51,16 \\
\hline Une a família & 11,63 & 0,00 & 88,37 \\
\hline Prefiro tomar fora de casa & 16,28 & 0,00 & 83,72 \\
\hline Precisa ser uma refeição rápida & 25,58 & 0,00 & 74,42 \\
\hline É comer lance & 2,33 & 0,00 & 97,67 \\
\hline Nunca tomo & 18,60 & 0,00 & 81,40 \\
\hline
\end{tabular}

Fonte: Pesquisa de campo (2018).

Explica Barbosa (2009) que essa é a refeição mais estável em termos de cardápio, sendo feitas poucas reivindicações acerca de preferências individuais e variedade por parte das pessoas. Seu menu é praticamente o mesmo para a maioria dos brasileiros, constando café preto ( $85 \%$ ), leite (73\%) e pão francês (76\%), independente do segmento de renda, faixa etária ou região do país. No caso investigado, o cardápio parece se aproximar, tendo em vista que $97,67 \%$ das consumidoras negam comer lanches durante essa refeição, optando preferencialmente pelo trio café, pão e manteiga ou algum outro doce de fruta.

Contrariando a pesquisa de Barbosa (2009; 2007), que revelou o café da manhã como a refeição mais importante do dia, nesse estudo ele foi considerado por apenas $48,84 \%$ da amostra, sendo aquelas que discordam dessa afirmação em maior número (51,16\%). Ele também é entendido enquanto uma refeição que pode ser feita com cautela e tranquilidade pelo maior número de consumidoras $(74,42 \%)$, que discordam da afirmação de que ele precisa ser tomado de forma rápida. Diferentemente dos grandes centros, caracterizados pela pressa, pela baixa interação social devido à rotina acelerada do mundo do trabalho. Por conta disso, o café da manhã, muitas vezes, é tomado na rua, nas lanchonetes, bares ou mesmo no trabalho, o que se apresenta como uma opção reduzida para a maioria das participantes aqui investigadas, sendo que apenas $16,28 \%$ disse preferir fazê-lo fora de casa. Nunca tomar café da manhã é uma alternativa para 18,60\% da amostra.

O almoço foi considerado a refeição mais importante do dia para $69,77 \%$ das respondentes, embora 30,23\% discordem dessa afirmação (Quadro 3). Segundo Barbosa (2007) essa importância atribuída ao almoço advém da sensação de saciedade e de 'peso no estômago' pelo fato de ser entendido como a refeição de maior sustância alimentar. No estudo de Castro e Abdala (2011), com estudantes e funcionários da Universidade Federal de Uberlândia, esse aspecto é confirmado por 
$65 \%$ dos participantes. A valoração atribuída ao almoço está associada a uma questão alimentar e nutricional da refeição ligada à correria do dia a dia, fornecer energia para um dia de trabalho, comer para ter nutrientes e permanecer saudável. Segundo as autoras, essas perspectivas estão atreladas à imersão das pessoas no modo de vida moderno, em que os espaços e tempos do comer são reestruturados pela constante atividade.

A valorização do almoço como a principal refeição pode ainda estar relacionada à sociabilidade possibilitada por ela. Do ponto de vista familiar, é entendida como aquela que mais 'une a família' (65,12\%), situação que também foi identificada por Barbosa (2007) em 48\% de seus respondentes e por Balem et al. (2017), mostrando o almoço como a refeição prioritária para as famílias. Essa propensão do almoço ocorrer em âmbito familiar está atrelada ao fato de que no país a escola não é, em sua grande maioria, em tempo integral, como ocorre em outros países. Além disso, existe uma relação direta entre o tamanho das cidades e a distância casa-trabalho que possibilitam às pessoas retornarem para suas casas para almoçar (BARBOSA, 2009).

Quadro 3 - Percepções sobre o almoço (\%)

\begin{tabular}{|l|c|c|c|}
\hline \multicolumn{1}{|c|}{ Almoço } & Concordo & $\begin{array}{c}\text { Não concordo/ } \\
\text { discordo }\end{array}$ & Discordo \\
\hline Mais importante do dia & 69,77 & 0,00 & 30,23 \\
\hline Une a família & 65,12 & 0,00 & 34,88 \\
\hline É comer marmite & 4,65 & 2,33 & 93,02 \\
\hline Quando a cozinha funciona & 79,07 & 0,00 & 20,93 \\
\hline Precisa ser uma refeição rápida & 20,93 & 2,33 & 76,74 \\
\hline Comemos o que sobra do jantar & 16,28 & 0,00 & 83,72 \\
\hline Nunca almoço & 2,33 & 0,00 & 97,67 \\
\hline
\end{tabular}

Fonte: Pesquisa de campo (2018).

O cardápio do almoço foi associado às preparações caseiras e habitualmente à comida feita na hora para ser ingerida naquela refeição. Nesse sentido, é entendido como a refeição em que a 'cozinha funciona' (79,07\%), sendo esse momento em que os pratos costumam ser preparados com alimentos frescos cozidos ou temperados um pouco antes da ingestão. Nos resultados do estudo de Balem et al. (2017), verifica-se que no almoço predominam alimentos relacionados à cultura alimentar, tais como arroz, feijão, massas, carnes, mandioca e saladas.

Nesse caso, 93,02\% das pessoas discordam que o almoço seja sinônimo de marmita, embora 4,65\% concordem e 2,33\% não concordem e nem discordem, por esporadicamente consumi-la quando ocorrem imprevistos associados ao trabalho, às viagens ou aos estudos. Os casos que o almoço é a sobra do jantar foi indicado por $16,28 \%$, enquanto $83,72 \%$ disse discordar dessa situação, que foi constatada principalmente quando as mulheres trabalham fora de casa e não dispõem de tempo para o cozimento dos alimentos, deixando-os prontos para serem aquecidos no dia seguinte. Isso foi evidenciado pela Consumidora 29: 'Eu mesma que faço a comida. Às vezes, quando não dá tempo, faço de noite pra comer de meio dia. Assim a gente faz as refeições caseiras, é mais gostoso e saudável'. Nesse sentido, mesmo nos casos em que se constatou restrição de horários, devido a trabalho, estudo ou 
outros compromissos, as evidências são de que sempre 'se dá um jeito' de preparar o alimento, nem que seja na noite anterior para se comer no dia seguinte.

Provavelmente essas são as mesmas consumidoras que concordam que por falta de tempo o almoço precisa ser uma refeição rápida (20,93\%), todavia, a maioria das participantes $(76,74 \%)$ discordam dessa situação, podendo realizá-la de forma tranquila. Essa não é a realidade dos grandes centros urbanos, como foi constatado por Barbosa (2009), pois o almoço é tido como uma refeição tumultuada e quase nunca visto como momento de lazer e relaxamento. Explica a autora que a interação social se centra naquilo que é preciso fazer de imediato, de modo que as atividades da rua invadem a casa de forma impessoal, orientando o ritmo das ações internas. Contudo, à medida que a semana avança, a sociabilidade tende a aumentar e até mesmo a qualidade da comida. O almoço de final de semana e especialmente o de domingo é aquele para o qual se dedica o maior tempo para preparação e consumo, caracterizando-se pela reunião familiar em torno da mesa. A escolha do cardápio foge do tradicional 'arroz com feijão' cotidiano, variando em termos de sabor e satisfação das preferências individuais (BARBOSA, 2007).

Nesse contexto, pode-se considerar o que é afirmado por Hirata e Kergoat (2007) de que há, ao longo do tempo, uma divisão sexual do trabalho que se estabelece a partir das diferenças de gênero, sendo as mulheres as principais responsáveis pelas atividades do lar, mesmo contribuindo igualitariamente com seus companheiros na manutenção econômica familiar e cumprindo com extensas jornadas de trabalho assalariado fora do lar. Nesse sentido, as decisões e conflitos relacionados a alimentação da família, recai consideravelmente a um conjunto de tarefas femininas, na qual a participação masculina, quando ocorre, se dá em proporções muito menores do que as tarefas destinadas às mulheres. Segundo as autoras, o trabalho doméstico foi enraizado histórica e socialmente enquanto uma atribuição pertencente a esfera feminina, na qual uma enorme carga de trabalho doméstico é efetuada gratuitamente pelas mulheres e completamente invisível aos interesses sociais capitalista.

Os dados sobre o jantar não o qualificam como a refeição mais importante do dia, 74,42\% das participantes discordam dessa afirmação (Quadro 4). O estudo de Castro e Abdala (2011) colabora com esse resultado ao se verificar que, apenas em $8 \%$ dos relatos, o associam à refeição principal, é entendido com certo descompromisso considerando que sua composição pode variar entre um simples lanche a uma 'verdadeira janta'. Além disso, não se caracteriza neste estudo como a refeição que mais reúne a família $(55,81 \%)$, apesar de ser apontado como aquela que habitualmente é realizada coletivamente (Gráfico 3).

Destaca Barbosa (2009) que o fato de o jantar doméstico ser simbolicamente representado como o centro da sociabilidade familiar no país, não implica necessariamente um comer em torno da mesa de maneira formal. Embora as pessoas estejam ao mesmo tempo no domicílio não significa que elas comam juntas no mesmo espaço. É comum que ocorra que cada membro do domicílio faça seu prato, retire a comida diretamente da panela ou prepare algo destoante dos demais membros e se sente em lugares diferentes da casa. O jantar pode ocorrer também de forma sequencial, mas havendo companhia, o que configura a existência de uma forma de sociabilidade na qual o afeto predomina. Essa situação pode ser identificada em casos em que, embora um dos membros já tenha jantado, 
fará companhia ao outro para que este não coma sozinho ou para saber a respeito do seu dia.

Quadro 4 - Percepções sobre o jantar (\%)

\begin{tabular}{|l|c|c|c|}
\hline \multicolumn{1}{|c|}{ Jantar } & Concordo & $\begin{array}{c}\text { Não concordo/ } \\
\text { discordo }\end{array}$ & Discordo \\
\hline Mais importante do dia & 25,58 & 0,00 & 74,42 \\
\hline Une a família & 44,19 & 0,00 & 55,81 \\
\hline Tenho mais tempo para comer & 83,72 & 0,00 & 16,28 \\
\hline É a sobra do almoço & 58,14 & 2,33 & 39,53 \\
\hline Quando a cozinha funciona & 30,23 & 0,00 & 69,77 \\
\hline É comer lance & 46,51 & 0,00 & 53,49 \\
\hline Nunca janto & 0,00 & 0,00 & 100,00 \\
\hline
\end{tabular}

Fonte: Pesquisa de campo (2018).

O jantar é a refeição em que as pessoas têm mais tempo para comer em $83,72 \%$ dos casos, pois após o jantar normalmente não se tem compromissos com o trabalho, escola ou demais obrigações. O cardápio na maioria dos casos $(58,14 \%)$ é a repetição do que foi servido no almoço, sendo que $69,77 \%$ da amostra não considera o funcionamento da cozinha nessa refeição. Embora todas as interlocutoras tenham declarado jantar diariamente, ao contrário do almoço, em que a comida é sustância, no jantar a sensação que se busca é por satisfação a partir de pratos mais leves e facilmente substituídos por um pequeno lanche e/ou saladas.

Nesse estudo, o jantar é a refeição mais facilmente substituída por lanches por $46,51 \%$ das respondentes, que declaram lanchar ao invés de ingerir pratos quentes. O que também é verificado por Castro e Abdala (2011) em 57\% das pessoas entrevistadas, para as quais o lanche esteve presente nas refeições noturnas. Nessa substituição ocorre o típico ato de 'beliscar' itens considerados parte de uma dieta 'natural' e 'saudável', como iogurte, cereais, saladas, sopas ou alimentos associados à cozinha local ou regional, como queijos, salames e polenta sapecada. Os lanches aqui considerados não se tratam unicamente do tipo prontos ou semiprontos, podendo ser pratos preparados em casa como, por exemplo, sanduíches caseiros, tapiocas, bolos, etc.

Em termos de perfis de consumo, o café da manhã, apesar de não ser considerado a refeição mais importante do dia para o total das participantes, foi assim considerado por $88,89 \%$ das consumidoras do perfil ' $B$ ' enquanto as entrevistadas do perfil ' $A$ ' foram aquelas que mais discordam dessa afirmação (66,67\%). Em termos de união familiar, não é considerado, de forma significativa, por nenhum dos perfis, apenas por $22,22 \%$ das participantes do perfil 'B'. Nesse caso, constatou-se essa situação principalmente quando existe a presença de crianças, idosos ou aposentados no domicílio compartilhando a primeira refeição do dia em conjunto.

O espaço do café da manhã é, preferencialmente para o perfil ' $A$ ' (100\%) o doméstico. Para os demais isso também é verdadeiro, contudo, algumas consumidoras dos grupos ' $B$ ' (11,11\%), 'C' (26,67\%) e ' $D$ ' (12,50\%) preferem fazê-lo fora de casa, devido a compromissos com trabalho e estudos ou pela falta de tempo em realiza-lo em casa. Assim, concordam que deva ser uma refeição rápida (perfis ' $B$ ' e 'C', 33,33\%; perfil ' $D$ ', 18,75\%). Em relação ao cardápio, quase todas parecem 
discordar do fato de comer lanches. Nunca tomar café da manhã é para 37,50\% das consumidoras do perfil ' $D$ ' uma opção, confirmando o que foi comentado anteriormente em relação ao fato de que em contextos com maior restrição no orçamento e, consequentemente, de alimentos, essa refeição torna-se a mais sujeita a ser eliminada da dieta.

O almoço é a refeição mais importante do dia para os perfis ' $A$ ' (100\%) e ' $D$ ' (81,25\%), em menor grau para o ' $C$ ' $(66,67 \%)$ e ' $B$ ' $(44,44 \%)$. Em termos de união familiar, apresenta-se uma perspectiva próxima para todos os perfis ('A', 'B', e ' $C$ ', os três com 66,67\% e 'D', 62,50\%), sendo considerada a refeição de maior sociabilidade familiar. Assim, independente da condição econômica das pessoas, elas fazem o almoço no espaço doméstico, já que esse é o momento em que a cozinha funciona, principalmente para o perfil 'A' (100\%), seguido do 'B' (88,89\%), do ' $D$ ' (75\%) e do ' $C$ ' (73,33\%). Além disso, é tida como aquela realizada de forma tranquila por ambos os perfis, indiferente de suas condições sociais e econômicas. Nesse caso, $81,25 \%$ das participantes do grupo ' $D$ ' discordam de que o almoço precisa ser feito de forma rápida, $77,78 \%$ do perfil ' $B$ ', $73,33 \%$ do ' $C$ ' e $66,67 \%$ do 'A'.

$A$ base da alimentação para essa refeição, ao que tudo indica, é a comida caseira, dificilmente ou quase nunca comprada fora pronta. Nesse sentido, a marmita é considerada apenas em casos de emergências por apenas 6,67\% das consumidoras do perfil ' $C$ ' e 6,25\% do perfil ' $D$ '. O cardápio do almoço é composto basicamente de comidas preparadas na hora e poucas pessoas concordaram com 0 fato de requentar as sobras do jantar. Das que requentam o jantar para comer no almoço, 33,33\% são participantes do perfil ' $A$ ', 18,75\% do perfil ' $D$ ', 13,33\% do perfil ' $C$ ' e $11,11 \%$ do perfil 'B'.

Para nenhum dos grupos de consumo, o jantar é considerado de forma significativa a refeição mais importante. Enquanto refeição que proporciona a união da família, observa-se que essa percepção tende a diminuir em conjunto com a renda domiciliar. Nesse caso, todas as participantes do perfil ' $A$ ' $(100 \%)$ concordam com a afirmativa de que ele une a família; o perfil 'B', em $55,56 \%$ dos casos; o ' $C$ ', em $40 \%$ e o ' $D$ ', em 31,25\%. Por outro lado, o jantar é a refeição em que todos os grupos têm mais tempo disponível para comer (perfil ' $B$ ', 100\%; perfil ' $D$ ', 81,25\%; perfil ' $C$ ', $80 \%$; perfil ' $A$ ', $66,67 \%)$. Em relação ao seu conteúdo, as consumidoras do perfil ' $B$ ' geralmente repetem com maior frequência aquilo que foi consumido no almoço $(77,78 \%)$, requentando os alimentos ou ao menos parte deles. Nesse caso, o perfil ' $A$ ' é o que menos tende a fazer isso (33,33\%), preferindo consumir pratos preparados unicamente para o jantar. Contudo, isso parece ser um aspecto que pode se alterar ao longo dos dias da semana já que a mesma proporção de consumidoras (33,33\%) disse 'não concordar nem discordar' dessa afirmação. Dessa forma, as respondentes desse perfil, $66,67 \%$, também concordam com o fato de o jantar ser o momento em que a cozinha funciona em casa.

Aquelas que preferem se alimentar de lanches são principalmente os do perfil ' $C$ ' (66,67\%), em menor proporção os do perfil ' $D$ ' (37,50\%) e com o mesmo número os perfis 'A' e 'B' (33,33\%). Não jantar não é uma possibilidade para nenhum dos perfis, revelando a importância dessa refeição em relação às demais. Além disso, verifica-se que a crença de que 'o jantar engorda' e pode ser retirado do sistema de refeições não se aplica nesse caso. 
De acordo com o Guia Alimentar (BRASIL, 2014), há evidências de que as circunstâncias que envolvem o consumo de alimentos, como, por exemplo, comer sozinho, alimentar-se sentado no sofá, estar diante da televisão (TV) ou partilhar uma refeição sentado à mesa, são importantes aspectos na indução dos alimentos que serão consumidos e em quais quantidades. Assim, procurou-se saber as principais atividades realizadas pelas consumidoras no momento das refeições (Gráfico 4).

Identificou-se que a principal atividade realizada por elas é, para 44,19\% da amostra, assistir televisão. Conforme Barbosa (2007), esse meio de comunicação possui relevância diante do ato de comer, pois se pode constatar que a refeição familiar é mediada por ela em $69 \%$ dos casos no Brasil. Sua presença é ainda mais consistente durante o jantar ao fornecer o pano de fundo para as conversas à mesa. Desse modo, às vezes, a televisão ganha proeminência sobre as conversas; em outras, ela desaparece e, em outras circunstâncias, os eventos que estão sendo televisionados são o motivo da conversa.

Gráfico 4 - Atividades realizadas durante as refeições

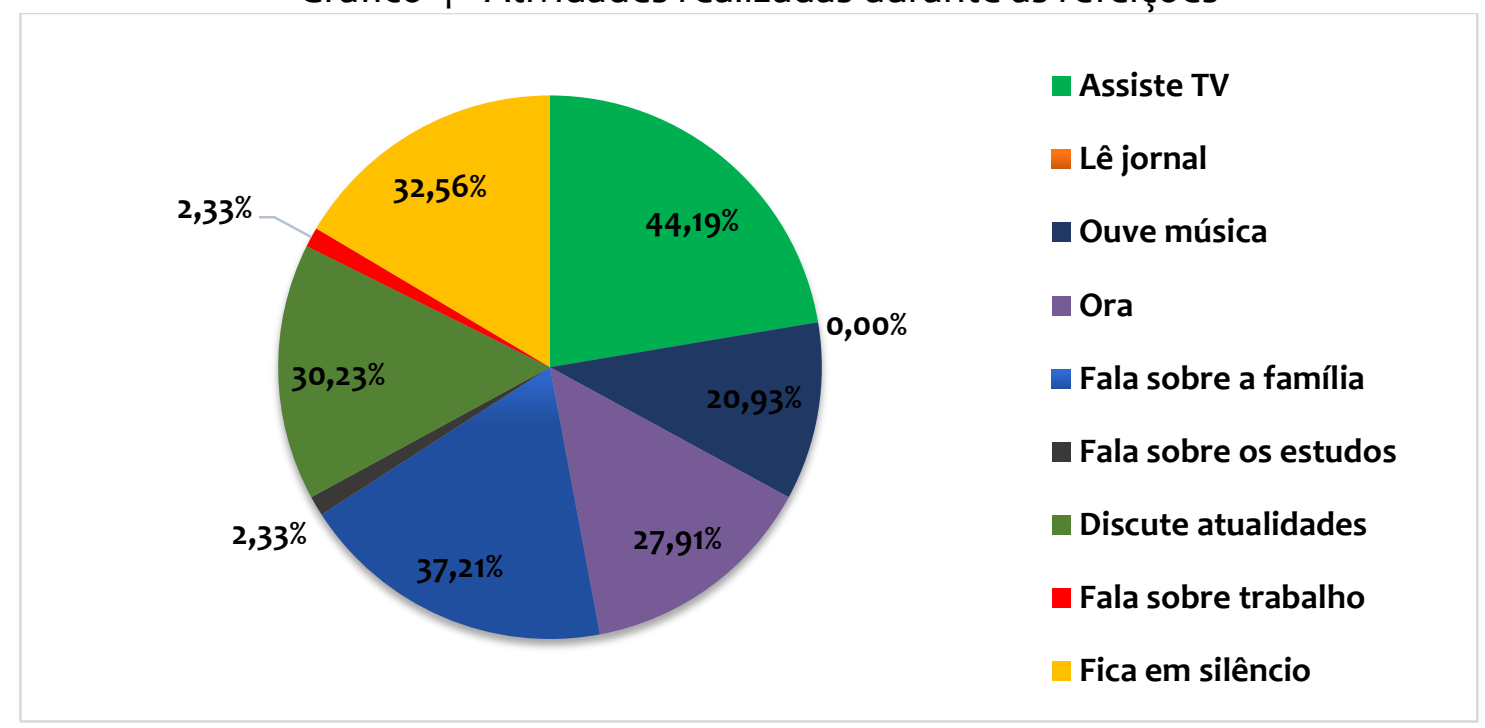

Fonte: Pesquisa de campo (2018).

$\mathrm{Na}$ análise de Castro e Abdala (2011), as relações sociais estabelecidas a partir da presença da televisão não chegam a inibir a conversação. Aliás, muitas vezes, as conversas podem partir de algum tema abordado por ela e iniciar um diálogo entre as pessoas. Do mesmo modo, as declarações do estudo de Barbosa (2007) compreendem que mesmo com a interferência da TV, as pessoas declaram tratar de assuntos da própria família quando se reúnem para as refeições.

Essa circunstância também é verificada no contexto desse estudo, já que $37,21 \%$ das pessoas declaram falar de assuntos referentes à família. Segundo Mintz (2001), a alimentação é um importante fator estruturante das relações sociais e de rituais, sendo um dos pilares do grupo familiar. As refeições podem ser entendidas enquanto espaços para conversar sobre a família, saber o que está ocorrendo na vida dos membros do grupo doméstico e reafirmar os laços familiares. Simmel (2004) elucida que a alimentação possui um forte papel socializador nas interações 
sociais, pois ao mesmo tempo em que as porções que se come são individuais, o ato de comer juntos passa a ideia de comunhão entre as pessoas.

Ficar em silêncio durante a ingesta é observado em 32,56\% dos domicílios. Cascudo (2011) diz que o silêncio nas refeições brasileiras é entendido pela crença de que comer é um ato religioso. Essa percepção pode ser observada no comentário da Consumidora 28: 'meu pai sempre dizia: a mesa é o mesmo que estar na igreja' e também pela fala da Consumidora 42 ao afirmar: 'na hora de comer é todo mundo em silêncio, a refeição é um momento sagrado'. Pelas falas, percebe-se que as refeições silenciosas remetem ao momento do sagrado e também são compreendidas como um espaço de agradecimento a partir da oração. Nesse caso, $27,91 \%$ das consumidoras disseram ter o hábito de orar antes de iniciar a ingesta, 0 que se mostra um achado interessante ao se comparar aos dados de Barbosa (2007), em que apenas $1 \%$ disse mediar às refeições a partir da oração.

As discussões sobre assuntos da atualidade, notícias e novidades em geral também fazem parte da rotina das atividades realizadas por 30,23\% da amostra durante as refeições. Além disso, 20,93\% dizem ouvir música no rádio enquanto comem e aproveitam para se informar das notícias locais. As conversas a respeito dos estudos (2,33\%) e do trabalho (2,33\%) surgem em menores proporções. A leitura de jornais não foi considerada pelas participantes como uma atividade praticada durante as refeições.

Em termos de perfis de consumo, as investigadas do perfil ' $A$ ' não consideram a presença da televisão nas refeições, para o perfil ' $B$ ' sua permanência é mais significativa em $55,56 \%$ dos casos; para o perfil ' $D$ ', em $50 \%$ e para o ' $C$ ', em 40\%. Na pesquisa de Castro e Abdala (2011), não se observou diferenças contrastantes a esse respeito, tendo em vista que, em todas as faixas de renda, considerou-se que, em algum momento, o aparelho fosse desligado durante a refeição. Os grupos 'A' (100\%), 'C' (46,67\%) e 'B' (44,44\%) são os que mais tendem a falar a respeito do contexto familiar; o grupo ' $D$ ' discute isso em menor grau de importância (12,50\%). Nesse caso, pode-se dizer que existe certa relação entre as duas variáveis, considerando que onde a presença da televisão, durante as refeições é maior, há a tendência a diminuir as conversas entre os membros do domicílio (perfis 'B' e 'D'). Ao contrário do que ocorre quando a televisão permanece desligada ou pelo menos em menor proporção de tempo e o diálogo entre as pessoas parece ser incentivado (perfis ' $A$ ' e ' $C$ ').

Ouvir música no rádio é um comportamento habitual apenas para os perfis ' $C$ ' (26,67\%) e 'D' (31,25\%). A atividade de orar antes da ingesta apresenta-se para o grupo 'D', em $37,50 \%$ dos casos; em seguida para o grupo 'C', em $26,67 \%$; e o grupo ' $B$ ', em $22,22 \%$. Falar sobre os estudos e o trabalho é uma característica apenas do perfil ' $B$ ' ainda que em apenas $11,11 \%$, em ambas as situações, não sendo assuntos mencionados pelos demais perfis. As discussões sobre atualidades parecem interessar mais as participantes do perfil 'A' (66,67\%), seguido do perfil ' $D$ ' (31,25\%), perfil ' $C$ ' $(26,67 \%)$ e menos as do grupo ' $B$ ' $(22,22 \%)$. Ficar em silêncio atingiu níveis próximos em todos os perfis, o grupo ' $A$ ', o ' $B$ ' e o ' $C$ ', todos com as mesmas proporções (33,33\%), enquanto o grupo ' $D$ ' $(31,25 \%)$ apresenta número um pouco menor. 


\section{Considerações finais}

O estudo teve o propósito de discutir as dinâmicas e os comportamentos alimentares acerca do consumo das principais refeições realizadas no ambiente doméstico de consumidoras residentes no espaço urbano do Município de Pato Branco/PR. Em geral, os resultados indicam que as principais refeições do dia são predominantemente realizadas no espaço doméstico e familiar, independente da condição socioeconômica das participantes. Essas foram identificadas como o café da manhã, almoço e jantar, e em menor proporção, o lanche da tarde.

O conteúdo das ingestas, especialmente, do café da manhã e do almoço, caracteriza-se por alimentos frescos preparados a partir de pratos caseiros para serem consumidos no momento das refeições. Esses parecem evidenciar práticas alimentares associadas a uma dieta composta significativamente de alimentos in natura, minimamente processados e alguns produtos processados. O consumo de lanches ou de ultra processados como, por exemplo, pratos prontos ou semiprontos, aparece de forma reduzida nas refeições, sendo mais propício a ocorrer em momentos rituais, de reuniões familiares, encontros entre amigos, nos fins de semana ou quando não se quer ou não pode cozinhar em função de outros compromissos.

Nesse sentido, a comida foi valorizada por sua origem caseira, características que foram atribuídas, sobretudo, aos aspectos de confiabilidade conferido aos alimentos. Nesse contexto, as refeições caseiras parecem se caracterizar por oferecer uma alimentação mais segura e dar sentido aquilo que já é conhecido, as quais também estiveram atreladas às memórias e a um imaginário relacionado à família, as tradições e aos saberes e sabores que a comida feita em casa pode proporcionar em termos de consumo.

Nesse caso, a prática do cozinhar torna-se uma atividade importante no sentido de preservação da cultura alimentar uma vez que evidência as preferências culinárias locais das quais o arroz com feijão ainda se constitui como o prato principal do cotidiano. Realizar refeições fora do espaço doméstico não é observado enquanto uma obrigação ou necessidade como acontece nos grandes centros urbanos, embora seja uma alternativa de laser e eventualidade. O fato de praticamente todas as ingestas serem feitas no ambiente doméstico também se deve ao município ao qual se realizou a investigação ser de médio porte, possibilitando o acesso e a mobilidade das consumidoras para fazer suas refeições em casa e prepará-las com maior disponibilidade de tempo. Assim, estes dois aspectos, comida natural e caseira são fundamentais para a boa nutrição do corpo e desenvolvimento de resistência orgânica, especialmente, se pensados frente a questões de doenças, como a crise atualmente vivenciada em torno do Corona Vírus.

Nesse contexto, evidencia-se que a busca e o preparo das refeições caseiras tratam-se de uma atividade quase que exclusivamente vinculada a esfera feminina, uma vez que, às mulheres compete gerenciar, tomar decisões e administrar os conflitos que envolvem a alimentação familiar. Isso indica, entre outras coisas, que apesar das transformações ocorridas ao longo do processo modernizante das sociedades, o trabalho doméstico atrelado a alimentação, recai consideravelmente a um conjunto de tarefas femininas, independentemente da situação 
socioeconômica domiciliar. Enquanto mães, esposas, avós e donas de casa, histórica e socialmente às mulheres compete o serviço de selecionar, preparar, manipular e servir os alimentos. Trabalho este realizado gratuitamente não apenas para elas mesmas, mas para os demais integrantes do grupo familiar e completamente invisível aos interesses da sociedade capitalista.

As análises a partir dos perfis de consumo evidenciaram as diferenças e particularidades em relação as condições socioeconômicas das participantes. Nesse sentido, a renda econômica pode ser considerada um elemento importante quando se trata do consumo de alimentos e da composição das dietas em termos de refeições. De um lado, pode proporcionar uma maior diversidade de alimentos no prato, do mesmo modo que reduzir ou impossibilitar o acesso quando se torna restrita. No estudo, os perfis de consumo com maior poder aquisitivo, perfis ' $A$ ' $e$ ' $B$ ', apresentam maior liberdade de escolha dos alimentos ao se constatar uma frequência maior no consumo das refeições e até mesmo acesso a uma maior variedade das escolhas alimentares.

Enquanto isso, os membros dos grupos de menor renda, perfis ' $C$ ' e ' $D$ ', apresentam certa vulnerabilidade social no sentido de contenção de gastos e uma redução do número de ingestas. Nesse caso, para os segmentos de menor renda, o café da manhã torna-se uma refeição intermitente, ficando restrita quando há situações de insegurança alimentar por falta de alimentos.

De modo geral, as refeições realizadas ao redor da mesa, especialmente o jantar, representam, simbolicamente, uma prática importante da sociabilidade como espaço da família, das conversas, da troca de informações e de diálogos do grupo domiciliar.

Nessa perspectiva, o olhar sobre as refeições permitiu compreender que o consumo e as práticas relacionadas a ele a partir das refeições apresentam-se como um importante elemento de observação de um processo social que está em constante mudança, mas que também se encontra em permanente recriação a partir de práticas e costumes que se voltam às tradições. Lançar luz sobre a dinâmica das refeições contemporâneas no espaço urbano, possibilitou compreender ainda que os simbolismos e significados da comensalidade podem sofrer alterações ao longo do tempo, mas não se limitam unicamente a reprodução das condições alimentares de contextos hegemônicos, nem mesmo em meio às intensas mudanças que ocorrem na modernidade alimentar.

\section{REFERÊNCIAS}

BALEM, T. A.; ALVES, E. O.; COELHO, J. C.; MELLO, A. L. P. As transformações alimentares na sociedade moderna: a colonização do alimento natural pelo alimento industrial. Revista Espacios, v. 38, n. 47, 2017.

BARBOSA, L. Comida e sociabilidades no prato do brasileiro. In: BARBOSA, L.; PORTILHO, F.; VELOSO, L (ORGs). Consumo: cosmologias e sociabilidades. Rio de Janeiro: Mauad X: Edur, 2009. 
BARBOSA, L. Feijão com arroz e arroz com feijão: o Brasil no prato dos brasileiros. Horizontes Antropológicos. Porto Alegre, ano 13, n. 28, 2007, pp. 87-116.

BRASIL. Ministério da Saúde. Secretaria de Atenção à Saúde. Coordenação Geral da Política de Alimentação e Nutrição. Guia alimentar para a população brasileira. $2^{\mathrm{a}}$ ed. Brasília/DF; Ministério da Saúde, 2014.

BAUMAN, Z. Vida para consumo: a transformação das pessoas em mercadorias. Tradução Carlos Alberto Medeiros. Rio de Janeiro: Jorge Zahar, 2008.

CANESQUI, A. M; GARCIA, R. W. Antropologia e Nutrição: um diálogo possível. Rio de Janeiro: Fiocruz, 2005.

CASCUDO, L. C. História da alimentação no Brasil, 4. Ed. São Paulo: Global, 2011.

CASTRO, L. A.; ABDALA, M. C. Televisão no momento das refeições. Horizonte Científico, v. $5, \mathrm{n}^{\circ} 2,2011$.

CHEUNG, T. L.; BATALHA, M. O.; LAMBERT, J. L. Comportamentos do consumidor de alimentos e suas maneiras de pensar a alimentação. In: CONTERATO, M. A.; NIEDERLE, P. A.; TRICHES, R. M.; MARQUES, F.C.; SCHULTZ, G. (Orgs.). Mercados e agricultura familiar: interfaces, conexões e conflitos. Porto Alegre: Via Sapiens. 2013, 358 pp. 99-113.

FISCHLER, C. El (h)omnívoro: el gusto, la cocina y el cuerpo. Barcelona: Anamgrama, 1995.

GIDDENS, A. As consequências da modernidade. São Paulo: Editora UNESP, 1991.

HIRATA, H.; KERGOAT, D. Novas configurações da divisão sexual do trabalho. Cadernos de pesquisa, v. 37, n. 132, p. 595-609, 2007.

IBGE. INSTITUTO BRASILEIRO DE GEOGRAFIA E ESTATÍSTICA. Pesquisa de orçamentos familiares (POF) 2008-2009: análise do consumo alimentar pessoal no Brasil. Rio de Janeiro: Instituto Brasileira de Geografia e Estatística, 2010.

MINTZ, S. W. Comida e antropologia: uma breve revisão. Revista Brasileira de Ciências Sociais. São Paulo, 2001, vol. 16, n. 47, pp. 31-41.

PANIGASSI, G., et al. Intra-family food insecurity and profile of food consumption. Revista de Nutrição. Campinas, SP, vol. 21, jul./ago., 2008, p 135-144.

POF. Pesquisa de Orçamentos Familiares. Instituto Brasileiro de Geografia e Estatística. Retirado de: https://agenciadenoticias.ibge.gov.br/agencia-sala-deimprensa/2013-agencia-de-noticias/releases/27298-pof-2017-2018-alimentos-frescose-preparacoes-culinarias-predominam-no-padrao-alimentar- 
nacional?fbclid=IwARoCokJVS5RLGouGPFiDy-os8CRR14gNuFn2NZJ91NneS6aA1Y949RNw5k Acesso em 15 abr. 2020.

POULAIN, J. P. Sociologias da alimentação: os comedores e o espaço social alimentar. Tradução de Rossana Pacheco da Costa Proença. $2^{\mathrm{a}}$. ed. Florianópolis: Editora da UFSC, 2013.

SEN, A. Poverty and famines: an essay on entitlement and deprivation. Oxford University Press Inc: New York, International Labour Organisation, 1981.

SIMMEL, G. Sociologia da refeição. Estudos Históricos, Rio de Janeiro, n 33, pp. 159$166,2004$.

WOORTMANN, K. Hábitos e ideologias alimentares em grupos sociais de baixa renda: relatório final. Série Antropologia. Brasília, 1978, n. 20, pp. 1- 114.

Marcio Gazolla. Doutor em Desenvolvimento Rural. Professor Titular da Universidade Tecnológica Federal do Paraná (UTFPR) / Programa de PósGraduação em Desenvolvimento Regional (PPGDR). Endereço: UTFPR Campus de Pato Branco. Programa de Pós-Graduação em Desenvolvimento Regional (PPGDR). Via do Conhecimento, km 1 (PR 493). Bairro Fraron. Caixa postal: 571. CEP 85503-390. Pato Branco/PR. marciogazolla1@gmail.com. Currículo Lattes: http://lattes.cnpq.br/0922348490725786.

Pahola Cristiny Viecelli. Mestre em Desenvolvimento Regional. Universidade Tecnológica Federal do Paraná (UTFPR) / Programa de Pós-Graduação em Desenvolvimento Regional (PPGDR). Endereço: UTFPR - Campus de Pato Branco. Programa de Pós-Graduação em Desenvolvimento Regional (PPGDR). Via do Conhecimento, km 1 (PR 493). Bairro Fraron. Caixa postal: 571. CEP 85503-390. Pato Branco/PR. paholaviecelli@hotmail.com. Currículo Lattes: http://lattes.cnpq.br/8792235829803048.

Como citar: GAZOLLA, Marcio; VIECELLI, Pahola Cristiny. Refeições e comportamentos à mesa: um estudo a partir de consumidoras urbanas. Redes (St. Cruz Sul, Online), Santa Cruz do Sul, v. 25, n. 2, p. 482-505, abr. 2020. ISSN 1982-6745. Disponível em: https://online.unisc.br/seer/index.php/redes/article/view/14858 Acesso em: 15 maio 2020. doi: https://doi.org/10.17058/redes.v25i2.14858 


\section{CONTRIBUIÇÃO DE CADA AUTOR}

a. Fundamentação teórico-conceitual e problematização: Marcio Gazolla e Pahola C. Viecelli b. Pesquisa de dados e análise estatística: Pahola C. Viecelli

c. Elaboração de figuras e tabelas: Pahola C. Viecelli

d. Fotos: Não possui

e. Elaboração e redação do texto: Marcio Gazolla e Pahola C. Viecelli

f. Seleção das referências bibliográficas: Marcio Gazolla e Pahola C. Viecelli

Fontes de financiamento: Coordenação de Aperfeiçoamento Pessoal de Nível Superior (CAPES). 